ORIGINAL ARTICLE

\title{
Experimental investigation on eucalyptus sawdust torrefaction for energy properties upgrading
}

\author{
Investigação experimental na torrefação da serragem de eucalipto para \\ aprimoramento de propriedades energéticas
}

\begin{abstract}
Robson Leal da Silva ${ }^{1,2}$ (D) , José Ricardo Patelli Júnior ${ }^{1}$ (D), Omar Seye ${ }^{1}$ (D),
Carolina Santana Michels ${ }^{1}$ (D), Isabele Oliveira de Paula ${ }^{3}$ (D), Paulo Smith Schneider ${ }^{4}$ (1)

${ }^{1}$ Faculdade de Engenharia - FAEN, Universidade Federal da Grande Dourados - UFGD, Dourados, MS, Brasil

2Programa de Mestrado em Engenharia Mecânica - PEM, Universidade Estadual de Maringá - UEM, Maringá, PR, Brasil

${ }^{3}$ Programa de Pós-graduação em Engenharia Mecânica - PPGEM, Universidade Estadual Paulista - UNESP, Ilha Solteira, SP, Brasi

4Programa de Pós-graduação em Engenharia Mecânica - PROMEC, Universidade Federal do Rio Grande do Sul - UFRGS,

Porto Alegre, RS, Brasil.
\end{abstract}

How to cite: Silva, R. L., Patelli Júnior, J. R., Seye, O., Michels, C. S., Paula, I. O., \& Schneider, P. S. (2020).

Experimental investigation on eucalyptus sawdust torrefaction for energy properties upgrading. Scientia Forestalis, 48(125), e2931. https://doi.org/10.18671/scifor.v48n125.01

\begin{abstract}
Wood harvesting presents excellent productivity in Brazil, which is one of the largest producers worldwide, Eucalyptus mainly. Torrefaction as a thermal treatment for woody biomass (Eucalyptus) was evaluated to improve its energy characteristics as material for combustion with biomass valuation. The methodology considered the torrefaction process with nine combinations, three residence times (20, 40 and 60 minutes) and three reaction temperatures $\left(180,220\right.$ and $\left.260^{\circ} \mathrm{C}\right)$ for wood samples. Quality aspects and quantitative parameters were determined experimentally, literature correlations and equations (proximate and ultimate analyzes, hygroscopicity, HHV, mass and energy yields). Main conclusions are: a) Hygroscopicity decreases (increasing hydrophobicity) providing a better storage condition aiming at commercialization; b) Volatile matter and fixed carbon contents are improved, $\Delta \mathrm{T}_{\mathrm{VM}, \mathrm{db}}=-4.7 \%$ and $\Delta \mathrm{T}_{\mathrm{FC}, \mathrm{db}}=+5.3 \%$, while $\mathrm{H} / \mathrm{C}$ and $\mathrm{O} / \mathrm{C}$ ratios tend to lower values when enhancing its quality; c) The darker the biomass after roasting (biochar), the better are its quality for energy purposes; d) Biomass upgrading occurs when increasing its HHV (up to $5.1 \%$, from 18.62 up to $19.58 \mathrm{MJ}^{\mathrm{k}} \mathrm{kg}^{-1}$ ), even with energy yield lowering when intensifying torrefaction ( $\eta_{E-Y i e l d}$ down to 0.9451 ); e) Torrefacted biomass (char) corresponds to intermediate energy properties between raw biomass and charcoal.
\end{abstract}

Keywords: Biomass pretreatment; Renewable energy; Pyrolysis; Solid biofuel; Industrial applications.

\section{Resumo}

A madeira apresenta excelente produtividade no Brasil (país tropical), que é um dos maiores produtores mundiais, eucalipto principalmente. Torrefação como tratamento térmico de biomassa lenhosa (eucalipto) foi avaliada para melhorar suas características de energia como matéria-prima para combustão para valorização da biomassa (energético e econômico). Metodologia considerou processo de torrefação com nove combinações, tempo de residência (20, 40 e 60 minutos) e temperaturas de reação $\left(180,220\right.$ e $\left.260{ }^{\circ} \mathrm{C}\right)$ para amostras de madeira; aspectos qualitativos e parâmetros quantitativos foram determinados experimentalmente, correlações de literatura e equações (análises imediata e elementar, higroscopicidade, PCS, e rendimentos em massa e energia). Principais conclusões são: a) higroscopicidade é reduzida (hidrofobicidade crescente), proporcionando uma melhor condição de armazenamento visando a comercialização; b) Teores de matéria volátil carbono fixo são melhorados, $\Delta \mathrm{T}_{\mathrm{VM}, \mathrm{db}}=-4,7 \%$ and $\Delta \mathrm{T}_{\mathrm{FC}, \mathrm{db}}=+5,3 \%$, enquanto as razões $\mathrm{H} / \mathrm{C}$ e $\mathrm{O} / \mathrm{C}$ tendem a valores reduzidos ao realçar sua qualidade; c) quanto mais escura a biomassa após a torrefação,

Financial support: CNPq 406898/2013-8

Conflict of interest: Nothing to declare.

Corresponding author: rlealsilva@hotmail.com

Received: 4 July 2018.

Accepted: 14 January 2019.

Editor: Francides Gomes da Silva Júnior.

(c) (i) This is an Open Access article distributed under the terms of the Creative Commons Attribution License, which permits unrestricted use,

c) distribution, and reproduction in any medium, provided the original work is properly cited. 
melhor é sua qualidade para fins energéticos; d) Aprimoramento da biomassa ocorre devido ao

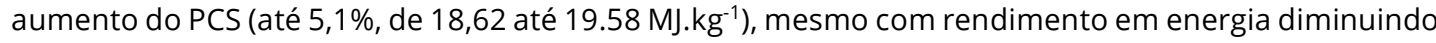

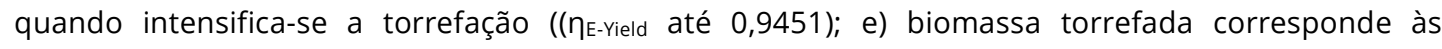
propriedades de energia intermediária entre biomassa original (in natura) e carvão vegetal.

Palavras-chave: Pré-tratamento de biomassa; Energia renovável; Pirólise; Biocombustível sólido; Aplicações industriais.

\section{INTRODUCTION}

Brazil is one of the largest producers of wood worldwide. Brazilian forest encompasses $516.10^{6}$ hectares, of which $\sim 99 \%$ are natural forests and only about $1 \%$ are planted, Eucalyptus and Pinus represent 93\% of planted genera (Heimann et al., 2015). Energy characteristics for commercial plantations of fast-growing species are frequently studied for both, Eucalyptus (Soares et al., 2014) and Pinus (Muñiz et al., 2014). Harvested wood is of high productivity in Brazil, a tropical country, reaching ten times more $\left(20-50 \mathrm{~m}^{3}\right.$.ha-1.year $\left.{ }^{-1}\right)$ than countries of temperate climate (Cortez et al., 2008).

Biomass can be obtained from plant species (woody and non-woody plants), from organic waste (agricultural, urban and industrial "residues") as well as from vegetable oils (bio-fluids) (Cortez et al., 2008). According to its origin it is possible to classify biomass as (Brand, 2010): forestry, agricultural, agro-industrial, and urban waste ("residues"). In Brazil, Eucalyptus typically has a planted origin, with main final products destination for charcoal, pulp and paper, and energy generation (thermal and electrical).

Thus, woody biomass (lignocellulosic origin) is classified as a renewable energy source, and it is used as a primary energy form (wood) or secondary (charcoal and derivatives). Historically in Brazil, residues from wood industries are destined for non-energy use (forest and wood products), but the international market already has a demand for compressed wood (pellets or briquettes) mainly for household appliances (European climate) while the Brazilian market (tropical country) demands it for energy use in commercial and industrial installations.

Combustion is usually the direct way to obtain energy (heat) from woody biomass, and thermal efficiency depends on its energy characteristics, provided by: proximate and ultimate analysis, High Heating Value (HHV), adiabatic temperature (theoretical), among others. Biomass characterization should be based on its final use and bring information that helps in the understanding of its determinant properties, inherent in each biomass (Sánchez., 2010).

Furthermore, biomass energy characteristics can be improved by compression (pelletizing or briquetting) or torrefacting (dry or conventional, in the absence of oxygen at $200-300^{\circ} \mathrm{C}$; or wet, in hydrothermal media or in hot compressed water at $180-260^{\circ} \mathrm{C}$ ), mechanical and thermal pretreatment processes respectively (Bach et al., 2016; Chen et al., 2015). Torrefacted woody biomass (pine, oak, and birch, mixture) presents increases in HHV (energy density) and fixed carbon content and reduced values of moisture and volatile matter content (with low energy content), $\mathrm{O} / \mathrm{C}$ and $\mathrm{H} / \mathrm{C}$ ratio and mass yield. That thermal process results in char (raw biomass after roasting), which is easier to grind and is hydrophobic (Wilk et al., 2016). Torrefaction can upgrade the biomass characteristics into a higher quality biofuel (Van der Stelt et al., 2011), with elasticity losses but with improved grindability and reactivity (Chen et al., 2015).

Woody biomass pyrolysis results in charcoal and similarly, torrefaction's main product is named as biochar (or char), together with gas and liquid by-products (volatile matter that comes out in the process). Thus, biochar contains around $90 \%$ and $70 \%$ of the $\mathrm{HHV}$ and weight (mass yield) of the original biomass (raw) with better combustion stability than raw biomass (Chen et al., 2015). Although high volatile matter and low moisture content facilitate fuel ignition, biochar is significantly drier, and thus it has a lower ignition temperature than raw biomass. On the other hand, it potentially increases the risk of self-ignition (Bach et al., 2016). Blending of the resulting biochar from torrefaction with fine charcoal particles (green fuel), or coal (fossil fuel) is a solution, since torrefaction provides a final product with more uniform properties. 
It is important to point out that the resulting char from torrefaction is a potential substitute of charcoal, in domestic or industrial applications. There are strong ambient and sustainability challenges that the steel industry faces in Brazil to obtain charcoal ("green steel"), while worldwide the use of coke or coal is common ("fossil steel"). One ton of pig iron using coal emits 1.9 tons of $\mathrm{CO}_{2}$ into the atmosphere while Eucalyptus charcoal results in only 0.8 tonnes of $\mathrm{CO}_{2}$ emission. Eucalyptus is native from Australia and was introduced to Brazil in 1900, covering about 5 million hectares and it is nowadays the world's more significant exporter of Eucalyptus products (Charcoal and pulp). Most of the plantation occurs in the Cerrado, a savannah region that covers $\sim 25 \%$ of Brazilian land and is home to about $5 \%$ of the planet's species (Caton, 2011).

The objective of the current study is to evaluate main energy properties for woody biomass (Eucalyptus), raw and torrefied. Upgrading biomass energy properties are evaluated and evaluated for: a) reaction temperature (180/220/260) and residence time (20/40/60 min); b) proximate (MC, VM, FC, Ash) analysis and hygroscopicity; c) ultimate analysis $(\mathrm{C}, \mathrm{H}, \mathrm{O})$, $\mathrm{H} / \mathrm{C}$ and $\mathrm{O} / \mathrm{C}$ ratios; d) HHV, mass and energy yields. Comparison and discussion about the torrefaction processes in the literature are given for woody biomass.

\section{MATERIAL AND METHODS}

\section{Woody biomass samples}

Wood residues typically have two main destinations: a) Energy use (direct combustion and incineration; gasification; pelleting and briquetting; pyrolysis); b) Forest and timber products: reuse, recycling and PMVA processing (value-added products), See Figure 1. Eucalyptus bark and wood were obtained from commercial products, and were milled in a knife mill (Solab, SL-31) with $250 \mu \mathrm{m}$ sieve opening. Then the samples were stored in glass dissectors and glass bottles, to avoid air interaction. A recirculation kiln (Sppencer scientific 420) was used for sample drying.
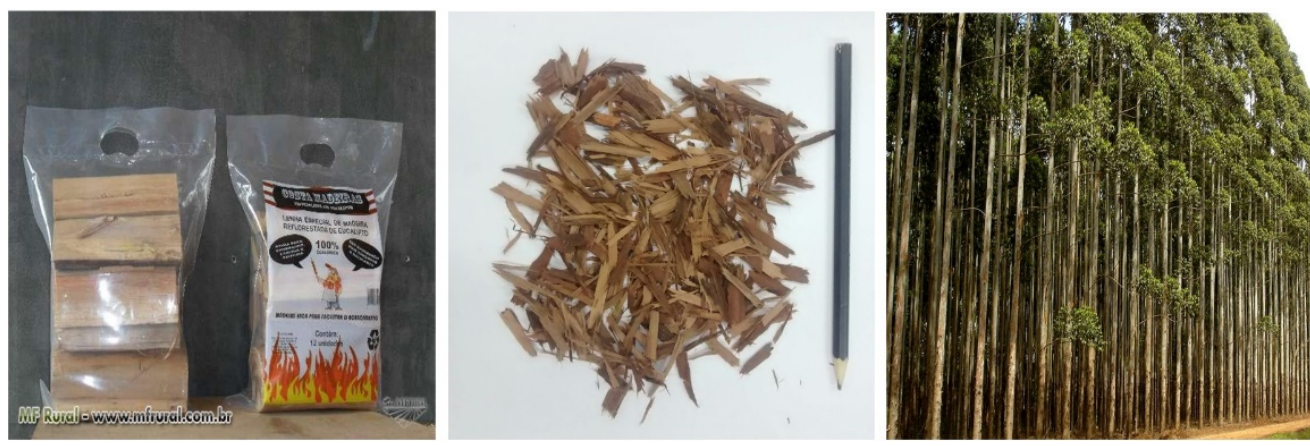

Figure 1. Eucalyptus wood package (5 kg), Bark samples (laboratory), and Eucalyptus forest (source: AgroBrasilTV, 2018)
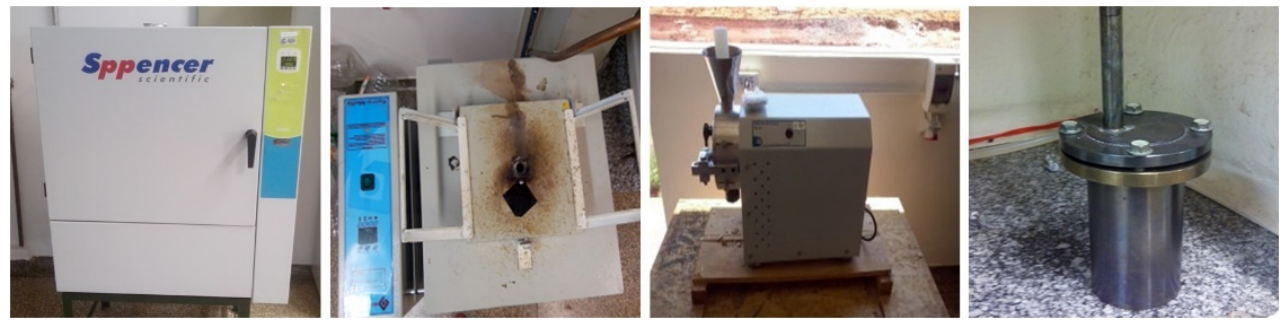

Figure 2. Equipment for biomass samples preparation, analysis and torrefaction: recirculating kiln, muffle furnace, knife mill and torrefaction device. 


\section{Experimental design: torrefaction procedure (temperature and residence time)}

Thermochemical pretreatment, i.e., conventional or Dry Torrefaction (DT) was applied to the woody biomass (Eucalyptus sawdust). The process included 3 (three) residence times $\left(20,40\right.$ and 60 minutes) and 3 (three) reaction temperatures $\left(180 \pm 10^{\circ} \mathrm{C} ; 220 \pm 10^{\circ} \mathrm{C}\right.$; $260 \pm 10^{\circ} \mathrm{C}$ ). Generally, DT residence time was less than $1 \mathrm{~h}$ (Bach et al., 2016), since biomass thermal degradation becomes very slowly beyond $1 \mathrm{~h}$ (Chen et al., 2015). DT is also called mild pyrolysis; since pyrolysis usually takes place at $350-650^{\circ} \mathrm{C}$. Samples were stored in glass dissectors and glass bottles, to avoid air interaction.

Torrefaction was inside a cylindrical container, positioned inside a muffle furnace (model xyz) previously heated up to reference temperatures. It was not possible to provide an inert atmosphere, but there was a restriction of oxygen intake with a metal lid/cover on top of the reaction container. After residence time elapsed, the recipient was removed for weighing, and torrefied samples removed to glass dissectors for cooling (within crucibles) and subsequent proximate analysis. Experimental procedure: 10 grams of eucalyptus wood with 0\% of moisture (after thoroughly drying, NBR 8112 (Associação Brasileira de Normas Técnicas, 1986) was crushed and introduced in the metal cylinder (Figure 2b) and then in the furnace (Figure 2c) previously heated to the torrefaction temperature. Thereafter, the furnace's door was closed, and the cylinder with biomass remained inside the equipment for an established time (20, 40 or 60 minutes). After expiry of the residence time, the biomass sample was removed and then placed in a Petri plate and introduced into the glass desiccator until reaching ambient temperature. Following that, the set (plate and sample) were weighed and results registered (see results section).

After the heating treatment (torrefaction), according to the experimental procedures described in this work, samples were split into $1 \mathrm{~g}$ parts. Then they were placed into the crucibles for proximate analysis (volatile matter and ash content, NBR 8112 (Associação Brasileira de Normas Técnicas, 1986). Seven days later (chosen time by authors), the moisture content was again determined to compare to its original condition (raw), all according to the methodology described for proximate analysis.

\section{Proximate and ultimate analysis}

Proximate analysis was obtained experimentally, in duplicate, according to NBR 8112 (Associação Brasileira de Normas Técnicas, 1986) for charcoal, and provided contents for: moisture content on wet and dry basis ( $\mathrm{T}_{\mathrm{MC}, \mathrm{wb}}$ and $\mathrm{T}_{\mathrm{MC}, \mathrm{db}} ; \Delta \mathrm{T}_{\mathrm{UM}} \leq 5 \%$; particle size $<19 \mathrm{~mm}$ ), volatile matter $\left(\mathrm{T}_{\mathrm{VM}} ; \Delta \mathrm{T}_{\mathrm{VM}} \leq 2 \% ; 0,150 \mathrm{~mm}<\right.$ particle size $\left.<0,210 \mathrm{~mm}\right)$, ashes $\left(\mathrm{T}_{\text {ash }} ; \Delta \mathrm{T}_{\text {Ash }} \leq 10 \%\right.$; particle size $<0,210 \mathrm{~mm}$ ) and fixed carbon $\left(T_{\mathrm{FC}}\right)$; this last one calculated from the difference (100 - Tum,wb $-T_{V M}-T_{a s h}$ ). Sample preparation recommendations were adapted from NBR 6922 and NBR 7402 (Associação Brasileira de Normas Técnicas, 1981, 1982).

Each biomass has its proper drying time, thus biomass samples should be left long enough in the recirculation dryer, until no changes in mass values are registered by a weight device (precision scale, $\pm 0.01 \mathrm{~g}$ ). In the dryer, drying time assessment for woody biomass samples (Eucalyptus) occurred, registering total mass (crucible and biomass) at each $\Delta \mathrm{t}=10$ minutes, until a total drying time of 30 minutes. $\mathrm{T}_{\mathrm{MC}}$ was determined using twenty (20) samples for Eucalyptus; wood and bark (10 samples for each).

Ultimate analysis is the weighed fraction for the most significant chemical elements in biomass of plant origin ( $T_{H}, T_{O}, T_{C}$, and others), and can be obtained experimentally by NBR 8631 (Associação Brasileira de Normas Técnicas, 1984) or via literature correlations (assessments, since experimental results are costly). The latter one was used in here, based on experimental results from proximate analysis, Equations 1-3 from Parikh et al. (2007), which neglect the effect of ash composition in elemental analysis; and, Equations 4-6 from Nhuchhen (2016), which is validated for a wide range of biomass (447 samples), including raw and torrefactied. Usually, polluting capacity is determined by Sulfur and Nitrogen contents ( $T_{S}$ and $T_{N}$ ), typically with small values in biomass originated from plant biomass, and high values in those of animal origin (ex: animal manure). Elemental composition and its atomic 
ratios ( $\mathrm{H} / \mathrm{C}$ and $\mathrm{O} / \mathrm{C}$, for instance) are of main importance to fuel HHV and combustion, providing assessment on enthalpy, exhaust gases and air volumes (Cortez et al., 2008).

$$
\begin{aligned}
& T_{C}(\%)=+0.4550\left(T_{V M, d b}\right)+0.6370\left(T_{F C, d b}\right) \\
& T_{H}(\%)=+0.0620\left(T_{V M, d b}\right)+0.0520\left(T_{F C, d b}\right) \\
& T_{O}(\%)=+0.4760\left(T_{V M, d b}\right)+0.3040\left(T_{F C, d b}\right) \\
& T_{C}(\%)=-35.9972+0.7698\left(T_{V M, d b}\right)+1.3269\left(T_{F C, d b}\right)+0.3250\left(T_{A s h, d b}\right) \\
& T_{H}(\%)=+55.3678-0.4830\left(T_{V M, d b}\right)-0.5319\left(T_{F C, d b}\right)-0.5600\left(T_{\text {Ash,db }}\right) \\
& T_{O}(\%)=+223.6805-1.7226\left(T_{V M, d b}\right)-2.2296\left(T_{F C, d b}\right)-2.2463\left(T_{\text {Ash, db }}\right)
\end{aligned}
$$

Where: $T_{H}(\%), T_{H}(\%)$, and $T_{H}(\%)$, are respectively, hydrogen, oxygen and carbon contents. Those correlations have been raised for proximate and ultimate analysis results in the following ranges (Parikh et al., 2007): 57.2\% $\leq \mathrm{T}_{\mathrm{VM}} \leq 90.6 \% ; 4.7 \% \leq \mathrm{T}_{\mathrm{FC}} \leq 38.4 \% ; 36.2 \% \leq \mathrm{T}_{\mathrm{C}} \leq 53.1$; $4.36 \% \leq \mathrm{T}_{H} \leq 8.3 \% ; 31.37 \% \leq \mathrm{T}_{\mathrm{O}} \leq 49.5 \%$; and, for raw (and torrefacted) ranges, careful recommended for high $\mathrm{T}_{H}$ values (Nhuchhen, 2016): 47.7-93.6\% (13.3-88.57) for $\mathrm{T}_{\mathrm{VM}} ; 0.67-$ $36.1 \%(11.25-82.74)$ for $\mathrm{T}_{\mathrm{FC}} ; 0.01-48.7 \%(0.08-47.62)$ for $\mathrm{T}_{\text {Ash }} ; 19.12-56.30 \%(35.08-86.28)$ for $\mathrm{T}_{\mathrm{C}}$; 2.00-7.36\% (0.53-7.46) for $\mathrm{T}_{H} ; 25.18-49.50 \%$ (4.31-44.70) for $\mathrm{T}_{\mathrm{O}}$.

\section{HHV and LHV}

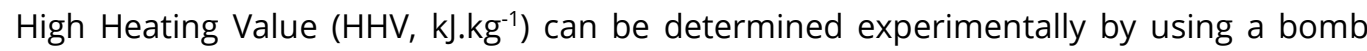
calorimeter (NBR 8633; Associação Brasileira de Normas Técnicas, 1984) or from empirical correlations based on the proximate analysis (Parikh et al., 2005), Equation 4; among other possibilities. Low Heating Value (LHV, kJ. $\left.\mathrm{kg}^{-1}\right)$ is obtained only from empirical correlations (Garcia, 2013), Equation 5.

$$
\begin{aligned}
& \operatorname{HHV}\left(M J \cdot \mathrm{kg}^{-1}\right)=0.3536\left(\mathrm{~T}_{\mathrm{FC}}\right)+0.1559\left(\mathrm{~T}_{\mathrm{VM}, \mathrm{db}}\right)-0.0078\left(\mathrm{~T}_{\text {Ash, db }}\right) \\
& \mathrm{LHV}\left(\mathrm{M} J \cdot \mathrm{kg}^{-1}\right)=H \mathrm{HV}_{\text {experimental }}-2240 .\left[\left(9 . \mathrm{T}_{H}+\mathrm{T}_{\mathrm{MC}, \mathrm{wb}}\right)\right]
\end{aligned}
$$

Where: HHV corresponds to the maximum amount of thermal energy that can be released through biomass (solid fuel) combustion. LHV corresponds to HHV less the amount of thermal energy required for change of state of water, from superheated steam to saturated liquid obtained, represented by Tum (Cortez et al.,2008).

\section{Mass and energy yields}

Torrefaction process implies in mass degradation (weight loss) and HHV upgrading (increase), which are quantified based on mass and energy yields in Equations 9 and 10. Those parameters ( $\eta_{M-\text {-ield }}$ and $\left.\eta_{E-\text {-rield }}\right)$, respectively indicate the remained mass and retained energy from original biomass (raw) after torrefaction, thus changes according to torrefaction process. Where: $\mathrm{m}_{\text {Raw-Biomass }}(\mathrm{g})$ and $\mathrm{m}_{\text {Torrefied-Biomass }}(\mathrm{g})$ are, respectively, the masses of In Natura and torrefied wood; while $\mathrm{HHV}_{\text {Raw-Biomass }}\left(\mathrm{MJ} . \mathrm{kg}^{-1}\right)$ and $\mathrm{HHV}_{\text {Torrefied-Biomass }}\left(\mathrm{MJ}^{-\mathrm{kg}^{-1}}\right)$ are the corresponding Higher Heating Values obtained from Equation 7. 


\section{RESULTS AND DISCUSSION}

Table 1 gives the results obtained for proximate and ultimate analysis; Eucalyptus wood and bark. Moisture and fixed carbon contents in bark samples are higher than those in wood, and the opposite for volatile matter content. Bark values for $\mathrm{T}_{\mathrm{Ash}} \sim 5 \%$ are considered high $\left(\mathrm{T}_{\mathrm{Ash}}=3 \%\right.$; Brand, 2010), probably indicating sample contamination. Nevertheless, other literature results for Eucalyptus bark, $\mathrm{T}_{\mathrm{VM}, \mathrm{db}}, \mathrm{T}_{\mathrm{FC}, \mathrm{db}}$, and $\mathrm{T}_{\mathrm{Ash}, \mathrm{db}}$ are: 55.6-75.1\%, 23.0-30.3 and 1.9-14.1 (Juizo et al., 2017); with ash content even higher than values here obtained. For nonwoody biomass, ash content is usually lower than $2 \%$, exception made for raw cotton ( $\left.T_{\text {ash }} \sim 5.5 \%\right)$, coconut shell $\left(T_{\text {Ash }} \sim 8.2 \%\right)$, sugarcane bagasse $\left(T_{\text {Ash }} \sim 11 \%\right)$ and rice husk $\left(T_{\text {Ash }} \sim 18 \%\right)$ (Cortez et al., 2008). As for comparisons for raw biomass (dry basis) proximate analysis, literature results indicate values close to the ones here obtained for Eucalyptus wood: 82.1\%, 17.56\%, and 0.34\% (Nones et al., 2015); 86.8\%, 13.0\%, and 0.16\% (Silva et al., 2017); 81.4\%, $17.82 \%$, and $0.79 \%$ (Cortez et al., 2008); respectively for $\mathrm{T}_{\mathrm{VM}, \mathrm{db}}, \mathrm{T}_{\mathrm{FC}, \mathrm{db}}$, and $\mathrm{T}_{\mathrm{Ash}} \mathrm{db}$.

Table 1. Eucalyptus wood and bark - proximate and ultimate analysis.

\begin{tabular}{|c|c|c|c|c|c|c|c|c|}
\hline Sample & $\begin{array}{c}T_{M c, d b} \\
(\%)\end{array}$ & $\begin{array}{c}T_{M C, w b} \\
(\%)\end{array}$ & $\begin{array}{c}\mathrm{T}_{\mathrm{VM}, \mathrm{db}} \\
(\%)\end{array}$ & $\begin{array}{l}T_{\text {VM, wb }} \\
(\%)\end{array}$ & $\begin{array}{c}T_{\text {ash,db }} \\
(\%)\end{array}$ & $\begin{array}{c}T_{\text {ash,wb }} \\
(\%)\end{array}$ & $\begin{array}{l}T_{\mathrm{FC}, \mathrm{db}} \\
(\%)\end{array}$ & $\begin{array}{c}\mathbf{T}_{\mathrm{FC}, \mathrm{wb}} \\
(\%)\end{array}$ \\
\hline Wood & 6.1 & 6.5 & 82.7 & 77.6 & 1.6 & 1.5 & 15.7 & 14.7 \\
\hline Bark & 9.1 & 10.1 & 77.3 & 70.2 & 5.7 & 5.2 & 17.1 & 15.5 \\
\hline Sample & $\mathrm{T}_{\mathrm{C}}(\%)^{1}$ & $T_{C}(\%)^{2}$ & & $\mathrm{~T}_{\mathrm{H}}(\%)^{1}$ & $T_{H}(\%)^{2}$ & & $\mathrm{~T}_{\mathrm{o}}(\%)^{1}$ & $T_{0}(\%)^{2}$ \\
\hline Wood & 49.0 & 47.6 & & 6.2 & 5.9 & & 42.6 & 44.1 \\
\hline Bark & 48.0 & 46.0 & & 5.8 & 5.7 & & 39.8 & 42.0 \\
\hline
\end{tabular}

${ }^{1}$ (Nhuchhen, 2016); ${ }^{2}$ (Parikh et al., 2007);

$\mathrm{T}_{\mathrm{C}}, \mathrm{T}_{\mathrm{H}}$, and $\mathrm{T}_{\mathrm{O}}$ values assessment (dry basis) are also available in Table 1. Experimental results in the literature indicates that values here obtained are a good approach for: $\underline{A}$ ) Bark: 51.2\%, 6.0\% and 37.8\%, with H/C 0.12 and O/C 0.74 (Vissotto et al., 2012); B) Wood: 53.3\%, $6.7 \%$ and 39.3\%,with $\mathrm{H} / \mathrm{C} \sim 0.13$ and $\mathrm{O} / \mathrm{H} \sim 0.74$ (Pérez et al., 2019); 44.4\% and 6.7\%, for $\mathrm{T}_{\mathrm{C}}$ and $\mathrm{T}_{\mathrm{H}}$, with $\mathrm{H} / \mathrm{C} \sim 0.15$ (Wilk et al., 2016); 32.3\% and 4.5\%, with $\mathrm{H} / \mathrm{C} \sim 0.14$ (Eucalyptus sawdust; Vissotto et al., 2012); 49.0\%, 5.9\% and 44.0\% (Cortez et al., 2008). Atomic ratios for H/C and $\mathrm{O} / \mathrm{C}$ influence directly the amount of energy that can be obtained from biomass combustion (McKendry, 2002). Assessment comparison indicates higher values for $T_{C}$ and $T_{H}$, and lower for To; in broader correlations (Nhuchhen, 2016) than in more simple ones (Parikh et al., 2007); where the former one is closer to experimental results in the literature for Eucalyptus wood.

Figures 3 and 4 show the visual modifications occurring on torrefied woody biomass (Eucalyptus). At $180^{\circ} \mathrm{C}$, for $1 \mathrm{~g}$ samples in crucibles, no visible changes are noticeable; on the other hand, $10 \mathrm{~g}$ samples have significant color changes and, as there was no cover on the crucibles, combustion occurred at the top (30 and 40 minutes results). Figure 4 indicates that, as temperature increases from 200 to $240^{\circ} \mathrm{C}$ ( $5 \mathrm{~g}$ samples; crucibles with cover), it intensified darkening for any residence time. In general (Figure 3), residence time seems to have a significant effect only because those images correspond to crucibles without cover, thus biomass at the top changed but not the whole sample inside the recipient. 
(A)

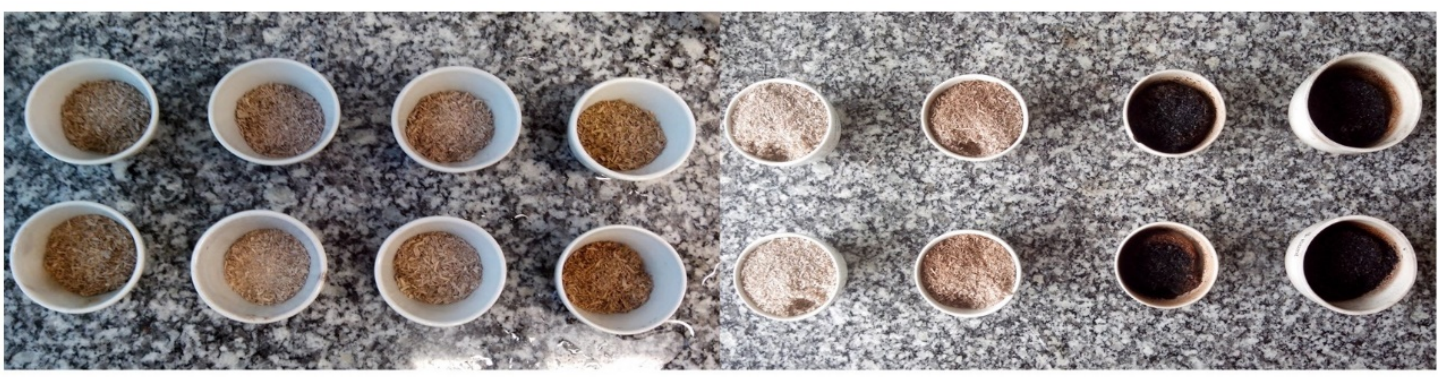

(B)

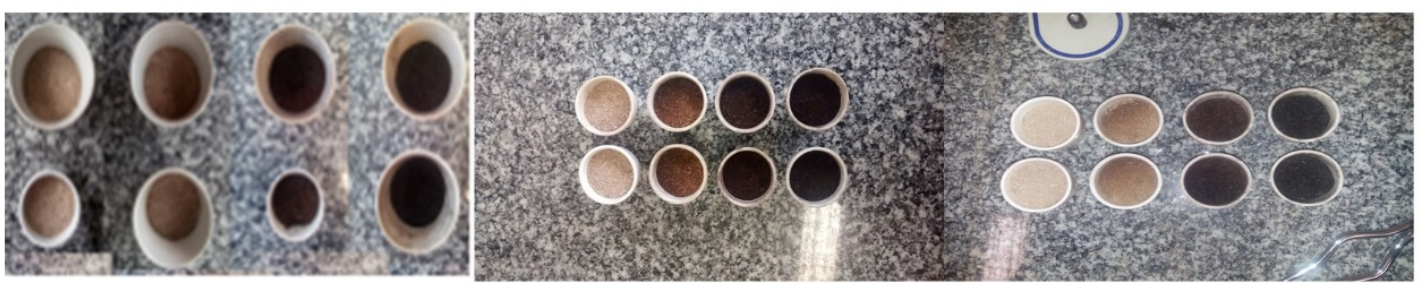

Figure 3. (A): Wood sawdust ( $1 \mathrm{~g}$ and $10 \mathrm{~g}$ samples) $-180^{\circ} \mathrm{C}$ and increasing residence time $(10,20,30$ and 40 minutes); (B) Wood sawdust (5g samples) $-200^{\circ} \mathrm{C}, 220^{\circ} \mathrm{C}$ and $240^{\circ} \mathrm{C}$ and increasing residence times $(10,20,30$ and 40 minutes).
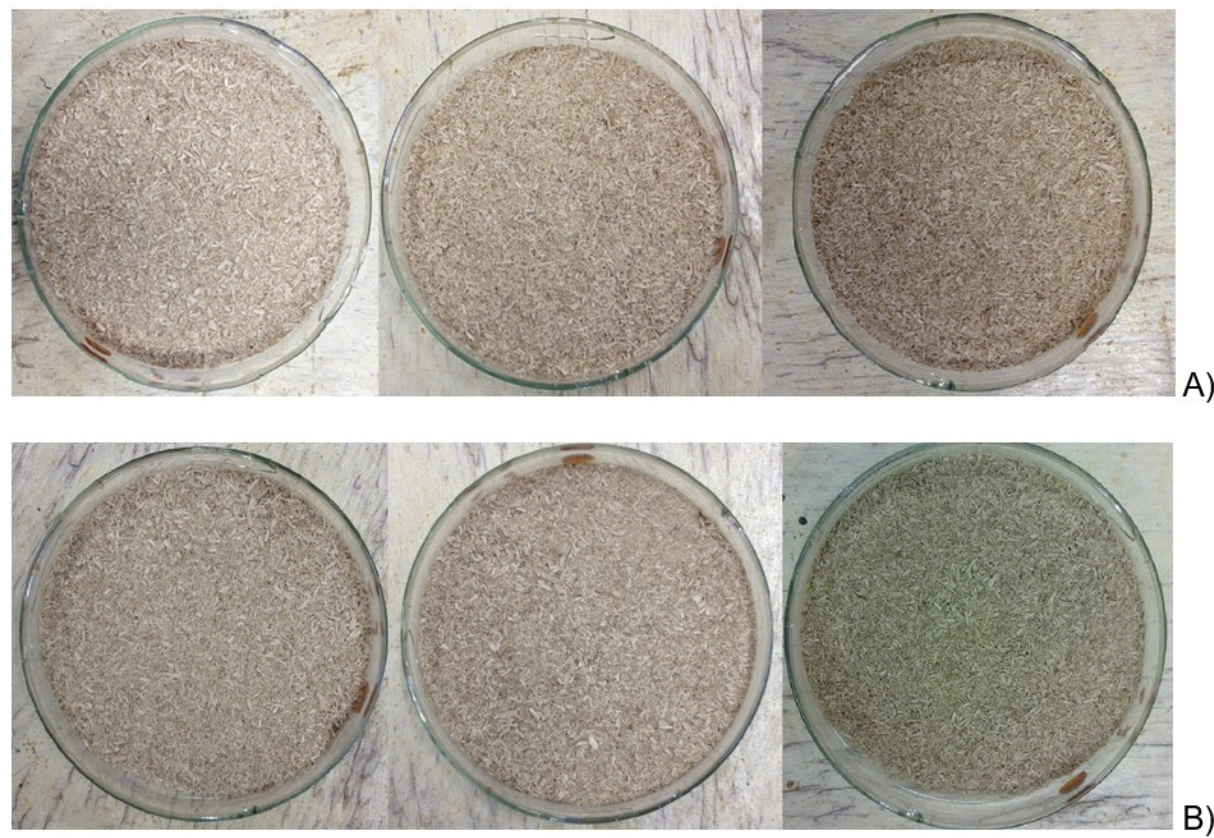

B)

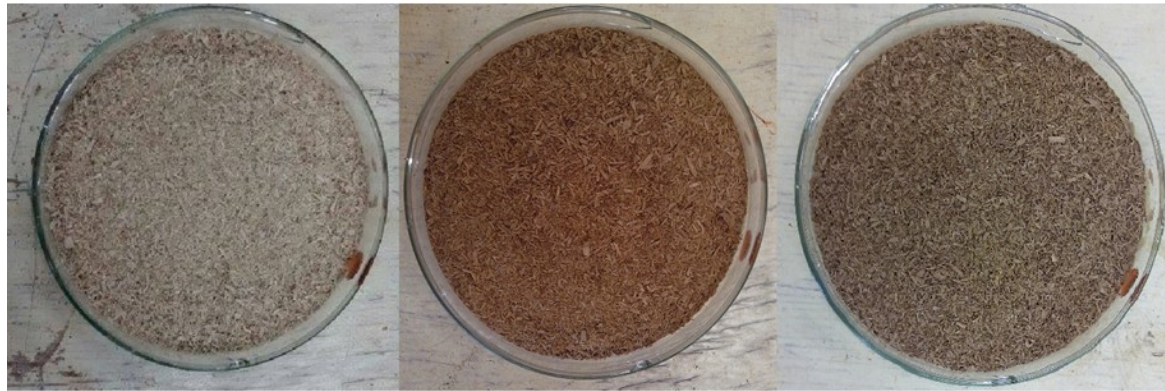

C)

Figure 4. Torrefied biomass (Eucalyptus sawdust) at different residence times (20, 40 and 60 minutes, from left to right) - (A) $180^{\circ} \mathrm{C}$; (B) $220^{\circ} \mathrm{C}$; (C) $260^{\circ} \mathrm{C}$. 
Figure 4 results are for crucibles with the cover on, restricting available air that allows combustion on the top surface of biomass, as occurred in Figure 3. Visual images analysis indicates that increases in torrefaction temperature (from 180 to $260^{\circ} \mathrm{C}$ ) has a significant effect on biomass properties (darkening as color changes), while it is rather low when comparing to increases in residence time (from 20 to 60 minutes). Little time of residence influence was also observed for wood residues torrefaction at $230 / 260 / 290^{\circ} \mathrm{C}$ and $30 / 60 / 90$ minutes (Wilk et al., 2016).

Furthermore, other woody biomass properties after torrefaction investigated next (Table 2) are mass and energy yields, and hygroscopicity. Hygroscopicity decreases, the ability to reabsorb humidity into the cell walls (Chen et al., 2015), for increases in both temperature and residence time; thus, increasing hydrophobicity, the ability to repel water or water-resistivity; changes are more prominent for high temperatures and reached minimum values $\left(\mathrm{T}_{\mathrm{MC}, \mathrm{wb}}=4.5 \%, \sim 69 \%\right.$ of the original moisture content, see Table 1 ) at $260^{\circ} \mathrm{C}$ and 60 minutes residence time. Thus, raw biomass hygroscopic nature turns into a hydrophobic characteristic for torrefied biomass, prolonging shelf-life in storage, lowering risk of biological deterioration and less expensive transportation (sawdust or pellets, for example).

Table 2. Torrefied wood (Eucalyptus, $\sim 10 \mathrm{~g}$ ) - proximate analysis, HHV (estimated), mass and energy variations.

\begin{tabular}{|c|c|c|c|c|c|c|c|c|c|c|c|c|}
\hline Sample & $\begin{array}{c}\mathrm{T}_{\mathrm{VM}, \mathrm{db}} \\
(\%)\end{array}$ & $\begin{array}{c}T_{\text {ash,db }} \\
(\%)\end{array}$ & $\begin{array}{l}\mathrm{T}_{\mathrm{FC}, \mathrm{db}} \\
(\%)\end{array}$ & $\begin{array}{c}\mathrm{T}_{\mathrm{c}} \\
(\%)^{1}\end{array}$ & $\begin{array}{c}T_{H} \\
(\%)^{1}\end{array}$ & $\begin{array}{l}T_{0} \\
(\%)^{1}\end{array}$ & $\begin{array}{l}T_{M C, w b} \\
(\%)^{2}\end{array}$ & $\begin{array}{c}\Delta_{\text {Mass }} \\
(\%)\end{array}$ & $\begin{array}{c}\eta_{M-Y i e l d} \\
(\%)\end{array}$ & 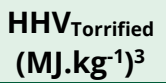 & $\begin{array}{l}\Delta_{\text {HHV }} \\
(\%)\end{array}$ & $\begin{array}{c}\eta_{\text {E-Yield }} \\
(\%)\end{array}$ \\
\hline $\begin{array}{c}\text { Raw } \\
\text { (In Natura) }\end{array}$ & 82.7 & 1.6 & 15.7 & 49.0 & 6.2 & 42.6 & $6.5 \%$ & - & - & 18.62 & - & - \\
\hline $180^{\circ} \mathrm{C}, 20 \mathrm{~min}$ & 81.0 & 1.0 & 18.0 & 50.6 & 6.1 & 41.8 & 8.0 & 2.2 & 97.8 & 18.98 & 1.9 & 1.9 \\
\hline $180^{\circ} \mathrm{C}, 40 \mathrm{~min}$ & 80.5 & 0.9 & 18.6 & 50.9 & 6.1 & 41.5 & 7.5 & 2.9 & 97.1 & 19.12 & 2.7 & 2.6 \\
\hline $180^{\circ} \mathrm{C}, 60 \mathrm{~min}$ & 80.0 & 0.9 & 19.1 & 51.2 & 6.1 & 41.3 & 6.5 & 3.5 & 96.5 & 19.22 & 3.2 & 3.1 \\
\hline $220^{\circ} \mathrm{C} ; 20 \mathrm{~min}$ & 82.5 & 1.0 & 16.5 & 49.7 & 6.2 & 42.5 & 8.5 & 4.6 & 95.4 & 18.69 & 0.4 & 0.3 \\
\hline $220^{\circ} \mathrm{C} ; 40 \mathrm{~min}$ & 81.1 & $1.0^{(*)}$ & 17.9 & 50.5 & 6.1 & 41.8 & 8.5 & 5.4 & 94.6 & 18.97 & 1.8 & 1.7 \\
\hline $220^{\circ} \mathrm{C} ; 60 \mathrm{~min}$ & 80.0 & 0.9 & 19.1 & 51.2 & 6.1 & 41.3 & 7.0 & 5.8 & 94.2 & 19.22 & 3.2 & 3.0 \\
\hline $260^{\circ} \mathrm{C} ; 20 \mathrm{~min}$ & 82.3 & 1.1 & 16.6 & 49.7 & 6.2 & 42.4 & 8.0 & 3.3 & 96.7 & 18.69 & 0.4 & 0.4 \\
\hline $260^{\circ} \mathrm{C} ; 40 \mathrm{~min}$ & 79.8 & 1.0 & 19.2 & 51.2 & 6.1 & 41.2 & 6.0 & 8.3 & 91.7 & 19.22 & 3.2 & 3.0 \\
\hline $260^{\circ} \mathrm{C} ; 60 \mathrm{~min}$ & 78.0 & 1.0 & 21.0 & 52.2 & 6.0 & 40.2 & 4.5 & 10.1 & 89.9 & 19.58 & 5.1 & 4.6 \\
\hline
\end{tabular}

${ }^{1}$ (Nhuchhen, 2016); ${ }^{2}$ Moisture content after 7 days elapsed; ${ }^{*}$ ) Original values indicated $3.7 \%$ probably due to sample contamination, which was corrected to $1 \%$ after a third sample analysis.

As for changes in proximate analysis, main differences are for $\Delta \mathrm{T}_{\mathrm{VM}, \mathrm{db}}=-4.7 \%(82.7 \% \mathrm{raw}$, down to $78 \%$ torrified) and $\Delta \mathrm{T}_{\mathrm{FC}, \mathrm{db}}=+5.3 \%$ (15.7\% raw up to $21 \%$ torrified), both conditions at $260^{\circ} \mathrm{C}$ and $60 \mathrm{~min}$. Similarly, Eucalyptus torrefaction at $240^{\circ} \mathrm{C}$ and $280^{\circ} \mathrm{C}(0.5 \mathrm{~h} / 1.0 \mathrm{~h} / 3.0 \mathrm{~h})$, $\Delta \mathrm{T}_{\mathrm{VM}, \mathrm{wb}}=12.8-28.6 \%$ and $\Delta \mathrm{T}_{\mathrm{FC}, \mathrm{db}}=12.9-27.6 \%$ according to Chen, Peng and $\mathrm{Bi}, 2015$. It is important to point out that differences are due to results on dry or wet basis, as well as samples origin and torrefaction process conditions. Ash content does not have significant variations in the results here obtained, but it is expected to increase (in weight percent) after torrefaction once it remains in the samples (biochar); thus Eucalyptus sawdust ash content is low, and variations are small enough since it was to not registered by a weight device (precision scale).

Woody biomass upgrading also occurs when evaluating HHV and mass, reaching $\Delta_{\mathrm{HHV}}=5.1 \%$ or $0.6 \mathrm{MJ} . \mathrm{kg}^{-1}$ and $\Delta_{\text {Mass }}=10.1 \%$, both at $260 \pm 10^{\circ} \mathrm{C}$ (60 minutes). Even higher HHV increases for Eucalyptus are possible when there are control improvements in process conditions, as for example $7.5 \%\left(250^{\circ} \mathrm{C}\right.$ for wood chips and oxygen entry limitation; Pereira et al., 2016), $10.8 \%\left(260 \pm 5^{\circ} \mathrm{C}\right.$ inside a rotating roaster; Silva et al., 
2017) and $15.7 \%\left(280^{\circ} \mathrm{C}\right.$ for wood chips and inert atmosphere control; Rodrigues \& Rousset, 2009). In general, torrefaction at any temperature or residence time always results in HHV increases and mass decreases, thus energy content is better indicated by energy yield, which computes both mass and HHV variations to provide a more robust parameter.

Ultimate analysis assessment also show upgrading when torrefaction occurs (Table 2), with $\mathrm{T}_{\mathrm{C}}$ increasing up to $52.2 \%$ and $\mathrm{T}_{\mathrm{O}}$ decreasing down to $40.2 \%$. As a consequence, $\mathrm{H} / \mathrm{C}$ and $\mathrm{O} / \mathrm{C}$ ratios (weight or mass basis) are presented and discussed in Figure 5 , with a comparison to other literature results. As torrefaction intensifies (temperature or time), $\mathrm{H} / \mathrm{C}$ and $\mathrm{O} / \mathrm{C}$ ratios tends to lower values (Chen et al., 2015); exception seems to have occurred only at $220^{\circ} \mathrm{C}$ and 20 minutes, with results partially corrected for ash content due to sample contamination and probably influenced other parameters under analysis. Literature results are consistent with general behavior that indicates lowering $\mathrm{H} / \mathrm{C}$ and $\mathrm{O} / \mathrm{C}$ ratios, as temperature or residence time are increased, intensifying the torrefaction process. $\mathrm{H} / \mathrm{C}$ ratio is minimum when using a reactor and carrier gas under rigorous control experimental setup (Lu et al., 2012), reaching $350^{\circ} \mathrm{C}$.
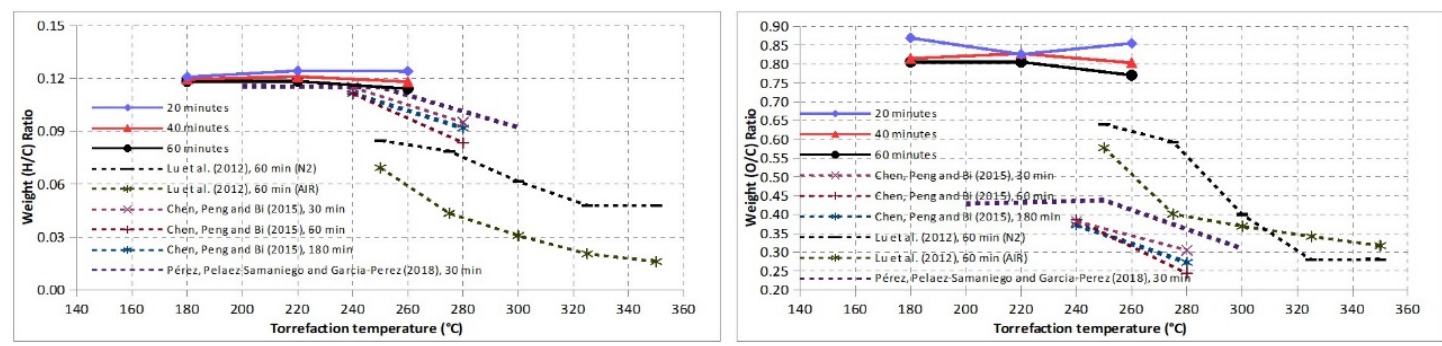

Figure 5. Weight ratios ( $\mathrm{H} / \mathrm{C}$ and $\mathrm{O} / \mathrm{C})$ for torrefied woody biomass (Eucalyptus): residence time and temperature influence.

Figure 6 indicates mass and energy yields results and comparison to other literature results. Mass (or gravimetric) yield consistently decreases with the residence time, and reaches $\eta_{\text {M-Vield-Minimum }} \sim 89.9 \%$ at $260^{\circ} \mathrm{C}$ and 60 minutes, the highest values for torrefaction temperature and residence time. Usually, weight loss is slight up to $235^{\circ} \mathrm{C}$, i.e., light torrefaction (Chen et al., 2015). Similarly, even with the mass reduction, energy yield only increases up to $\eta_{E-\text {-rield- }}$ Maximum $4.6 \%$, at $260^{\circ} \mathrm{C}$ and 60 minutes. This is consistent for Eucalyptus under similar conditions: $\eta_{M-\text {-rield }} \sim 55 \%$ and $\eta_{\text {E-yield }}$ 65\%, for $300^{\circ} \mathrm{C} @ 30 \mathrm{~min}$ (Pérez et al., 2019); 75.7\% < $\eta_{\mathrm{M} \text {-rield }}$ $<96.8 \%$ and $83.9 \%<\eta_{\text {E-rield }}<99.0 \%$, for $170-260^{\circ} \mathrm{C} @ 15 \min$ (Silva et al., 2017); 80.1\% < $\eta_{\text {M-rield }}$ $<96.4 \%$ and $92.8 \%<\eta_{E-\text { Yield }}<100.2 \%$, for $220-280^{\circ} \mathrm{C} @ 60$ min (Rodrigues \& Rousset, 2009). Longer torrefaction times favor thermal degradation for cellulose and hemicellulose (Lu et al., 2012). As a whole, results obtained in this work also are influenced by atmosphere and temperature control inside reaction cylinder and muffle furnace, which could be improved to provide even better yields.
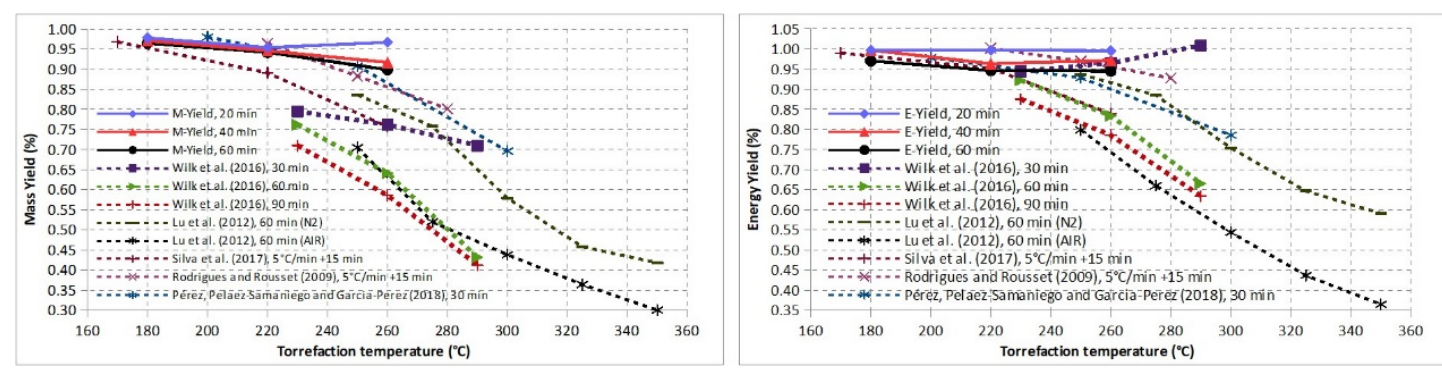

Figure 6. Mass and energy yields for torrefied woody biomass (Eucalyptus): residence time and temperature influence. 
Quantitative differences when comparing results obtained in the present work and literature are also influenced by samples origin and process parameters as residence times and reaction gases (inert atmosphere or not). Nevertheless, the qualitative behavior observed is consistent with literature reviews on torrefaction processes, since actual results show decreases for $T_{V M, d b}$ and $\eta_{M-Y i e l d}$, while $T_{F C, d b}$ and $\eta_{E-\text { Yield }}$ increases, with high reaction temperature and residence times. More prominent variations for Eucalyptus wood parameters in this work are for changes in $\Delta \mathrm{T}\left(180-260^{\circ} \mathrm{C}\right)$ than in $\Delta \mathrm{t}$ (20-60 minutes). Thus it shows that reaction temperature influence prevails over the residence time, which is consistent with literature reviews on biomass torrefaction (Bach et al., 2016; Chen et al., 2015).

\section{CONCLUSIONS}

Torrefaction as a thermal treatment for woody biomass (Eucalyptus) was evaluated to improve its energy characteristics as material for combustion with biomass valorization (energy and economic values). Main conclusions are:

a) Hygroscopicity decreases, thus increasing hydrophobicity, with a minimum of $\mathrm{T}_{\mathrm{Mc}, \mathrm{wb}}=4.5 \%, \sim 69 \%$ of the original moisture content, providing a better storage condition for future usage or commercialization.

b) Volatile matter and fixed carbon contents are improved, $\Delta \mathrm{T}_{\mathrm{VM}, \mathrm{db}}=-4.7 \%$ and $\Delta \mathrm{T}_{\mathrm{FC}, \mathrm{db}}=+5.3 \%$, while $\mathrm{H} / \mathrm{C}$ and $\mathrm{O} / \mathrm{C}$ ratios tend to lower values and enhancing its quality.

c) The darker the biomass after torrefaction (biochar), the better are its quality for energy purposes, thus torrefaction temperatures at $260^{\circ} \mathrm{C}$ and 60 minutes of residence time are recommended.

d) Upgrading occurs when increasing its HHV (up to $5.1 \%$, from 18.62 up to $19.58 \mathrm{MJ}^{\mathrm{kg}} \mathrm{kg}^{-1}$ ), even with energy yield lowering when intensifying torrefaction ( $\eta_{E-\text {-rield }}$ down to 0.9451 ).

e) Torrified biomass (char) corresponds to intermediate energy properties between raw biomass and present charcoal, keeping up to $90 \%$ and $70 \%$ of its original HHV and weight (mass yield), respectively.

\section{ACKNOWLODGEMENTS}

R\&D Project CNPq "Avaliação de sistemas de potência operando em coqueima (cofiring) ou queima combinada de carvão com resíduos", coordinated by UFRGS (Paulo Smith Schneider, Dr. Eng.). Scholarships received (August/2014, December/2015) from IC/ITI - Scientific Initiation and Industrial Technology Initiation, granted by CAPES - Coordination for Improvement of Higher Education Personnel and CNPq - National Council for Scientific and Technological Development. Also to UFGD/Energy Engineering for facilities and technical support.

\section{REFERENCES}

AgroBrasilTV. (2018). Retrieved in 2018, May 22, from agrobrasiltv.com.br

Associação Brasileira de Normas Técnicas - ABNT (1981). NBR 6922: ensaios físicos - determinação da massa especifica (densidade à granel). Rio de Janeiro: ABNT.

Associação Brasileira de Normas Técnicas - ABNT (1982). NBR 7402: carvão vegetal - determinação granulométrica. Rio de Janeiro: ABNT.

Associação Brasileira de Normas Técnicas - ABNT. (1984). NBR 8633: carvão vegetal: determinação do poder calorífico. Rio de Janeiro: ABNT.

Associação Brasileira de Normas Técnicas - ABNT. (1986). NBR 8112: carvão vegetal: análise imediata. Rio de Janeiro: ABNT.

Bach, Q.-V., Tran, K., \& Skreiberg, Ø. (2016). Hydrothermal pretreatment of fresh forest residues: effects of feedstock pre-drying. Biomass and Bioenergy, 85(1), 76-83. https://doi.org/10.1016/j.biombioe.2015.11.019

Brand, M. A. (2010). Energia da biomassa florestal. Rio de Janeiro: Interciência.

Caton, P. (2011). Guardians of the Cerrado. Geographical, 8, 18-28. Retrieved in 2018, May 22, from http://geographical.co.uk/magazine/issues?start=45 
Chen, W.-H., Peng, J., \& Bi, X. T. (2015). A state-of-the-art review of biomass torrefaction, densification and applications. Renewable \& Sustainable Energy Reviews, 44(1), 847-866. http://dx.doi.org/10.1016/j.rser.2014.12.039.

Cortez, L. A. B., Lora, E. E. S., \& Gómez, E. O. (2008). Biomassa para energia (1. ed.). Campinas: Unicamp. Garcia, R. (2013). Combustíveis e combustão industrial (2. ed.). Rio de Janeiro: Interciência.

Heimann, J. P., Dresch, A. R., \& Almeida, A. N. (2015). Demanda dos Estados Unidos por carvão vegetal brasileiro. Ciência Florestal, 25(2), 437-445. http://dx.doi.org/10.5902/1980509818463.

Juizo, C. G. F., Lima, M. R., \& Silva, D. A. (2017). Qualidade da casca e da madeira de nove espécies de Eucalipto para produção de carvão vegetal. Agrária, 12(3), 386-390. http://dx.doi.org/10.5039/agraria.v12i3a5461.

Lu, K. M., Lee, W. J., Chen, W. H., Liu, S. H., \& Lin, T. C. (2012). Torrefaction and low temperature carbonization of oil palm fiber ans eucalyptus in nitrogen and air athmospheres. Bioresource Technology, 123, 98-105. PMid:22940305. http://dx.doi.org/10.1016/j.biortech.2012.07.096

McKendry, P. (2002). Energy production from biomass (part 1): overview of biomass. Biomass and Bioenergy, 83(1), 37-46. PMid:12058829. http://dx.doi.org/10.1016/S0960-8524(01)00118-3.

Muñiz, G. I. B., Lengowski, E. C., Nisgoski, S., Magalhães, W. L. E., Oliveira, V. T., \& Hansel, F. (2014). Characterization of Pinus spp needles and evaluation of their potential use for energy. Cerne, 20(2), 245250. http://dx.doi.org/10.1590/01047760.201420021358.

Nhuchhen, D. R. (2016). Prediction of carbon, hydrogen, and oxygen compositions of raw and torrified biomass using proximate analysis. Fuel, 180, 348-356. http://dx.doi.org/10.1016/j.fuel.2016.04.058.

Nones, D. L., Brand, M. A., Cunha, A. B., Carvalho, A. F., \& Weise, S. M. K. (2015). Determinação das propriedades energéticas da madeira e do carvão vegetal produzido a partir de Eucalyptus Benthamii. Floresta, 45(1), 57-64. http://dx.doi.org/10.5380/rf.v45i1.30157.

Parikh, J., Channiwala, S. A., \& Ghosal, G. K. A. (2007). A correlation for calculating elemental composition from proximate analysis of biomass materials. Fuel, 86(12-13), 1710-1719. http://dx.doi.org/10.1016/j.fuel.2006.12.029.

Parikh, J., Channiwala, S. A., \& Ghosal, G. K. A. (2005). correlation for calculating HHV from proximate analysis of solid fuels. Fuel, 84(5), 487-494. http://dx.doi.org/10.1016/j.fuel.2004.10.010.

Pereira, M. P. C. F., Costa, E. V. S., Pereira, B. L. C., Carvalho, A. M. M. L., Carneiro, A. C. O., \& Oliveira, A. C. (2016). Torrefação de cavacos de eucalipto para fins energéticos. Pesquisa Florestal Brasileira, 36(87), 269275. http://dx.doi.org/10.4336/2016.pfb.36.87.1093.

Pérez, J. F., Pelaez-Samaniego, M. R., \& Garcia-Perez, M. (2019). Torrefaction of fast-growing Colombian wood species. Waste and Biomass Valorization, 10(6), 1655-1667. http://dx.doi.org/10.1007/s12649-017-0164-y.

Rodrigues, T. O., \& Rousset, P. L. A. (2009). Effects of torrefaction on energy properties of Eucalyptus grandis wood. Cerne, 15(4), 446-452. Retrieved in 2018, May 22, from http://www.cerne.ufla.br/site/index.php/CERNE/article/view/179

Sánchez, C. G. (Ed.). (2010). Tecnologia da gaseificação de biomassa. Campinas: Átomo.

Silva, C. M. S., Vital, B. R., Carneiro, A. C. O., Oliveira, A. C., Araújo, S. O., \& Magalhães, M. A. (2017). Energy properties of wood particles torrified at different temperatures. Revista Árvore, 41(4), 1-7. http://dx.doi.org/10.1590/1806-90882017000400004.

Soares, V. C., Bianchi, M. L., Trugilho, P. F., Pereira, A. J., \& Höfler, J. (2014). Correlações entre as propriedades da madeira e do carvão vegetal de híbridos de eucalipto. Revista Árvore, 38(3), 543-549. http://dx.doi.org/10.1590/S0100-67622014000300017.

Van der Stelt, M. J. C., Gerhauser, H., Kiel, J. H. A., \& Ptasinski, K. J. (2011). Biomass upgrading by torrefaction for the production of biofuels: a review. Biomass and Bioenergy, 35(9), 3748-3762. http://dx.doi.org/10.1016/j.biombioe.2011.06.023.

Vissotto, J. P., Mazzonetto, A. W., Neves, R. C., Sánchez, E. M. S., \& Sánchez, C. G. (2012). Caracterização de Pinus, Eucaliptus, casca de Eucaliptus e resíduos florestais e de destoca para fins energéticos. In Anais do VII Congresso Nacional de Engenharia Mecânica (CONEM). São Luiz: ABCM. CD-ROM.

Wilk, M., Magdziarz, A., Kalemba, I., \& Gara, P. (2016). Carbonisation of wood residue into charcoal during low temperature process. Renewable Energy, 85(1), 507-513. http://dx.doi.org/10.1016/j.renene.2015.06.072.

Authors'contributions: RLS: conceptualization, investigation, formal analysis, validation, visualization, methodology, writing; JRPJ and OS: supervision, resources; CSM and IOP: data curation, formal analysis, visualization, investigation; PSS: funding acquisition, project administration, writing. 